\title{
PERAN GURU MENANAMKAN PENDIDIKAN KARAKTER DI SEKOLAH DASAR NEGERI MOJOREJO 2 SUKOHARJO
}

\author{
Siti fatimah \\ PPKn, Universitas Veteran Bangun Nusantara Sukoharjo \\ imaeimaey2015@gmail.com
}

\begin{abstract}
Abstrak
Tujuan penelitian ini adalah untuk mendeskripsikan fenomena pendidikan karakter pada siswa SD N Mojorejo 2, Sukoharjo. Jenis penelitian menggunakan penelitian kualitatif. Subyek penelitian yaitu guru di SD N Mojorejo 2, Sukoharjo. Sementara itu, teknik pengumpulan data menggunakan observasi dan wawancara. Teknik analisis data penelitian ini yaitu analisis interaktif yang meliputi pengumpulan data, penyajian data dan kesimpulan. Hasil penelitian menunjukan bahwa peran guru dalam mendidik karakter sebagai 4 aspek, antara lain peran sebagai fasilitator, peran sebagai motivator, peran sebagai desain program, dan peran sebagai pemberi keteladanan. Karakter akan menjadi roh diri siswa jika siswa benar-benar mengamalkan apa yang telah dididik oleh guru dengan sikap, perilaku dan perbuatan yang mencerminkan perilaku yang baik dan sesuai dengan aturan yang berlaku di lingkungan sekitar siswa.
\end{abstract}

Kata kunci: Peran Guru, Pendidikan Karakter, Karakter

\begin{abstract}
The purpose of this study is to describe the phenomenon of character education in students of SD N Mojorejo 2, Sukoharjo. This type of research uses qualitative research. The research subjects were teachers at SD N Mojorejo 2, Sukoharjo. Meanwhile, data collection techniques using observation and interviews. The data analysis technique of this research is complete interactive data analysis, data presentation and conclusions. The results showed the teacher's role in educating character as 4 aspects, including the role as facilitator, role as motivator, program role as design, and role as role model. Character will be the spirit of students if students truly practice what has been educated by the teacher with attitudes, behaviors and behaviors that reflect good behavior and in accordance with the rules that apply in the environment around students
\end{abstract}

Keywords: teachers, character education, character 


\section{PENDAHULUAN}

Pendidikan adalah sesuatu yang telah ada sejak sejarah manusia dimulai. Pendidikan merupakan sebuah proses penyempurnaan diri yang dilakukan manusia secara terus-menerus. Hal ini disebabkan karena pada dasarnya manusia memiliki kekurangan dan keterbatasan, maka untuk mengembangkan diri serta melengkapi kekurangan dan keterbatasannya, manusia berproses dengan pendidikan.

Salahsatunya pendidikan yang bertujuan untuk mengembangkan potensi diri siswa yaitu melalui nilai-nilai karakter. Pada kondisi saat ini, beberapa siswa masih ada yang kurang dalam penerapan nilai-nilai karakter di lingkungan sekolah. Misalnya ada siswa yang kurang rapi dalam berpakain, tidak masuk sekolah tanpa surat izin, datang terlambat ke sekolah, tidak mengerjakan tugas dari guru, dan lain sebagainya. Hal ini dipengaruhi adanya pengaruh lingkungan sekitar sekolah yang kurang mendukung. Melalui pendidikan karakter di sekolah diharapkan peserta didik mampu menjadi pribadi yang utuh, serta terbiasa menerapkan nilai-nilai karakter yang baik dalam kehidupan sehari-harinya baik dilingkungan sekolah maupun di lingkungan masyarakat.

Pentingnya pendidikan karakter juga disampaikan oleh Zainal Aqib (2012) yang mengatakan bahwa perlunya pendidikan karakter tertuang dalam UndangUndang Nomor 20 Tahun 2003 tentang sistem pendidikan nasional. Dalam pasal 3 UU tersebut dinyatakan bahwa pendidikan nasional berfungsi mengembangkan kemampuan dan membentuk watak serta peradaban bangsa yang bermartabat dalam rangka menceerdaskan kehidupan bangsa, bertujuan untuk berkembangnya potensi peserta didik agar menjadi manusia yang beriman dan bertakwa kepada Tuhan Yang Maha Esa berakhlak mulia, sehat, berilmu, cakap, kreatif, mandiri dan menjadi warga negara yang demokratis serta bertanggung jawab.

Secara khusus pentingnya pendidikan karakter itu sendiri adalah juga dikaitkan dengan era dan tantangan globalisasi saat ini. Pada era global ini tidak hanya perubahan ilmu pengetahuan dan teknologi melainkan adanya pergeseran aspek nilai dan moral dalam kehidupan bermasyarakat. Lingkungan sekolah saat ini memiliki peran sangat besar dalam pembentukan karakter siswa. Peran guru 
sangat dibutuhkan sebagai seorang model sekaligus mentor siswa dalam mewujudkan perilaku berkarakter meliputi olah pikir, olah hati dan olah rasa. Masyarakat berharap guru dapat mencerminkan nilai-nilai moral seperti kejujuran, keadilan, dan kode etik profesional (Lickona, 2013).

Guru sebagai seseorang yang berperan penting dalam pendidikan karakter sekaligus orang yang menentukan berhasil atau tidaknya proses pembelajaran. Peran guru dalam membentuk karakter di SD N Mojorejo 2, Sukoharjo sudah berjalan, tetapi ada sebagian siswa yang melanggar peraturan disekolah. Misalnya ada beberapa siswa yang tidak mengerjakan PR dengan alasan dengan ketinggalan dirumah, lupa mengerjakan PR, karena materinya belum paham, siswa tidak mengenakan seragam atribut secara lengkap dengan alasan ketinggalan dirumah dan lupa membawanya, gaduh atau ramai sendiri dalam kelas.

Fenomena di atas menunjukkan bahwa kurangnya pendidikan karakter pada siswa. Oleh sebab itu, penelitian ini bertujuan untuk mendeskripsikan fenomena pendidikan karakter pada siswa SD N Mojorejo 2, Sukoharjo.

\section{METODE PENELITIAN}

Penelitian ini dilakukan di SD N Mojorejo 2, Sukoharjo. Jenis penelitian menggunakan penelitian kualitatif. Adapun subyek penelitian yaitu guru dan siswa di SD N Mojorejo 2, Sukoharjo. Sementara itu, teknik pengumpulan data menggunakan observasi dan wawancara. Observasi dipergunakan oleh peneliti untuk melihat dan mengamati karakter yang muncul pada siswa SD N Mojorejo 2, Sukoharjo pada saat proses pembelajaran di kelas. Disamping itu, wawancara dilakukan pada guru dan siswa untuk mendapatkan informasi karakter ketika pembelajaran di kelas. Teknik analisis data penelitian ini yaitu analisis interaktif yang meliputi pengumpulan data, penyajian data dan kesimpulan. Menurut Miles \& Huberman (2014: 16) analisis terdiri dari tiga alur kegiatan yang terjadi secara bersamaan yaitu: reduksi data, penyajian data, penarikan kesimpulan/verifikasi. Mengenai ketiga alur tersebut secara lebih lengkapnya adalah sebagai berikut:

1). Reduksi Data. Reduksi data diartikan sebagai proses pemilihan, pemusatan perhatian pada penyederhanaan, pengabstrakan, dan transformasi data 
kasar yang muncul dari catatan-catatan tertulis di lapangan. Reduksi data berlangsung terus-menerus selama proyek yang berorientasi penelitian kualitatif berlangsung.

2). Penyajian Data. Miles \& Huberman membatasi suatu penyajian sebagai sekumpulan informasi tersusun yang memberi kemungkinan adanya penarikan kesimpulan dan pengambilan tindakan. Mereka meyakini bahwa penyajianpenyajian yang lebih baik merupakan suatu cara yang utama bagi analisis kualitatif yang valid, yang meliputi: berbagai jenis matrik, grafik, jaringan dan bagan.

3). Menarik Kesimpulan. Penarikan kesimpulan menurut Miles \& Huberman hanyalah sebagian dari satu kegiatan dari konfigurasi yang utuh. Kesimpulan-kesimpulan juga diverifikasi selama penelitian berlangsung.

Adapun penjelasan analisis data di atas dapat disajikan dalam bagan berikut ini.

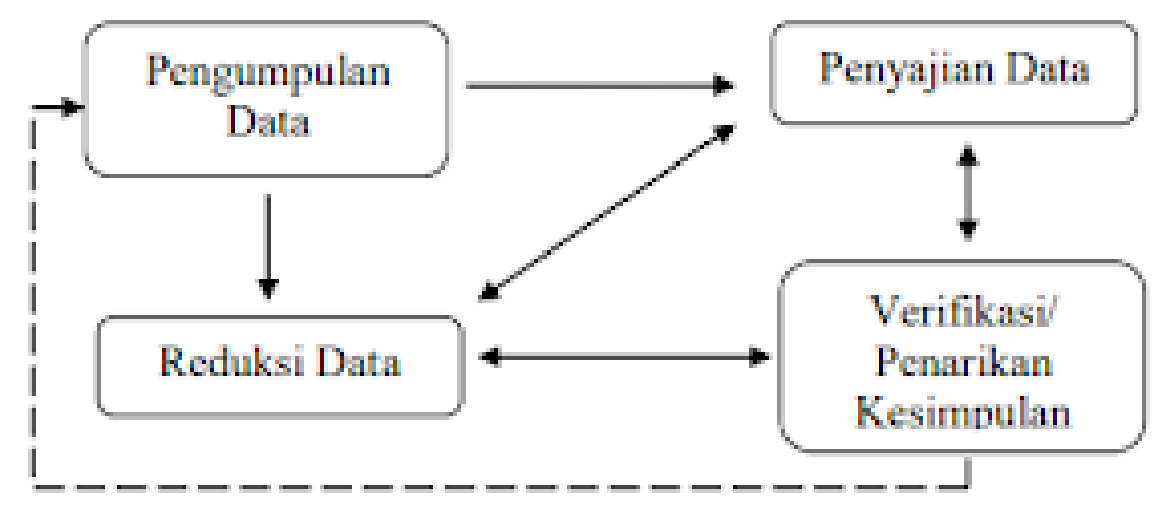

Gambar 1. Model Analisis Interaktif (Milles \& Huberman, 2014)

\section{HASIL PENELITIAN DAN PEMBAHASAN}

Peran guru di SD N Mojorejo 2, Sukoharjo dalam pembentukan karakter diperoleh berdasarkan hasil observasi dan wawancara yang dilakukan peneliti pada guru dan siswa melaksanakan pembelajaran di kelas.

a. Guru sebagai fasilitator pembelajaran 
Peran guru salahsatunya membantu siswa untuk mempermudah siswa dalam pemahaman materi mengenai teknologi komunikasi masa lalu dan masa sekarang. Variasi model, metode yang digunakan oleh guru dengan menggunakan metode STAD, ceramah dan tanya jawab dengan menggunakan media gambar dalam materi mengenai teknologi komunikasi masa lalu dan masa sekarang. Guru membuat sebuah kegiatan diskusi didalam kelas yang terdiri dari 5 sampai 6 orang untuk melakukan pembahasan mengenai materi mengenai teknologi komunikasi masa lalu dan masa sekarang dengan melakukan pengajaran berdialog dimana ketika guru menjelaskan dan siswa belum paham mereka akan bertanya, kemudian ketika guru bertanya siswa memiliki antusias yang tinggi untuk menjawab pertanyaan dari guru.

Guru juga membentuk kelompok diskusi dalam pengerjaan tugas maupun dalam memahami materi pembelajaran. Sehingga proses penyampaian materi pembelajaran dapat dilakukan dengan baik dan siswa mampu bekerjasama dengan kelompok diskusi mereka, bertanggung jawab terhadap tugas yang diberikan guru, serta saling peduli dengan kelompok diskusi mereka.

Seperti yang diungkapkan oleh guru kelas VII SD N Mojorejo 2, Sukoharjo ketika wawancara:

"Saat pembelajaran di kelas untuk menanamkan karakter dalam bentuk disiplin, tanggung jawab, serta peduli sosial siswa, saya membuat kelompok diskusi kemudian mengarahkan mereka untuk mendiskusikan materi pembelajaran secara berkelompok dengan tenang dan bekerjasama dengan teman satu kelompoknya.".

Hal ini juga sependapat dengan Mulyasa (2013) bahwa indikator variabel peran guru sebagai fasilitator terdiri dari 3 ukuran yaitu 1) tindakan guru untuk membantu siswa dalam pembelajaran dengan memiliki sikap yang baik, 2) pemahaman terhadap peserta didik melalui kegiatan dalam pembelajaran dan 3) memiliki kompetensi dalam menyikapi perbedaan individual peserta didik.

b. Guru sebagai motivator pembelajaran 
Peran guru selanjutnya adalah memotivasi setiap aktivitas dan perbuatan siswa. Memotivasi artinya guru memberi sebuah dorongan terhadap siswa. Setiap siswa memiliki karakter yang baik namun terkadang tanpa adanya sebuah motivasi dari luar mereka tidak akan mengerti mengapa perlu memiliki karakter yang baik. Guru pada saat pembelajaran di kelas guru beberapa kali mengingatkan siswa untuk mengerjakan tugas dengan baik, memperhatikan pembelajaran, masuk ke kelas setelah istirahat dengan tepat waktu, melakukan kerjasama saat diberi tugas kelompok, saling membantu ketika ada yang mengalami kesulitan.

Pernyataan tersebut di sampaikan oleh guru kelas VIII SD N Mojorejo 2, Sukoharjo:

"Pemberian motivasi kepada siswa kita karena biasanya karakter mereka itu baik namun karena kurangnya motivasi dari luar maka karakter baik yang mereka miliki kurang terlihat. Maka saya sering berpesan kepada mereka untuk selalu bersikap dan bertindak sesuai dengan nilai-nilai yang ada dengan mematuhi peraturan yang berlaku."

Demikian pula dari argumen manizar (2015) bahwa peran seorang guru bukan hanya semata-mata mentransfer ilmu mata pelajarannya kepada siswa tetapi, guru juga sebagai motivator bagi siswa agar memiliki prestasi dalam belajar. karena siswa yang memiliki motivasi yang lebih tinggi akan mencapai hasil belajar yang lebih tinggi dibandingkan dengan siswa yang memiliki motivasi rendah atau tidak memiliki motivasi sama sekali.

c. Guru sebagai desainer program

Peran guru yang ketiga adalah sebagai pendesain dalam setiap perencanaan dan aktivitas di kelas, apalagi yang berkaitan dengan karakter terwujud dalam bentuk Rencana Pelaksanaan Pembelajaran (RPP). Pembuatan program pendidikan karakter di SD N Mojorejo 2, Sukoharjo guru mempertimbangkan karakteristik siswa yang akan dihadapinya. Guru membuat program pendidikan dengan menekankan aspek kerjasama sehingga siswa mampu saling mengingatkan apabila ada temannya yang melanggar peraturan yang ada di kelas. 
Seperti yang dikutip dalam wawancara dengan guru kelas VII SD N Mojorejo 2, Sukoharjo:

"Perencanaan program yang dibuat sebelumnya dengan memahami karakter dan kebutuhan siswa. Kemudian saya memilih metode pembelajaran yang sesuai sehingga siswa mampu menerima materi pembelajaran yang saya berikan”.

Perencanaan program perlu disiapkan dengan matang oleh guru. Pendapat Zein (2016: 281) bahwa persiapan mengajar harus jelas kompetensi dasar yang akan dimiliki oleh peserta didik, apa yang harus dilakukan, apa yang harus dipelajari, bagaimana mempelajarinya, serta bagaimana guru mengetahui bahwa peserta didik telah menguasai kompetensi tertentu. Aspekaspek tersebut merupakan unsur utama yang secara minimal harus ada dalam setiap persiapan mengajar sebagai pedoman guru dalam melaksanakan pembelajaran dan membentuk kompetensi peserta didik.

d. Guru sebagai pembimbing dan sumber keteladanan

Falsafah digugu lan ditiru, makana tersebut menyiratkan guru sebagai pembimbing pada siswa mengenai nilai karakter yang seharusnya dilakukan siswa. Meminta siswa untuk tenang dan memperhatikan saat guru menjelaskan materi di depan kelas. Menegur siswa yang berberilaku kurang sopan dan menasehatinya agar tidak mengulanginya kembali. Guru sebagai sumber keteladanan memberi contoh yang baik kepada siswa, karena siswa meniru apa yang dilakukan guru. Guru datang ke sekolah 30 menit sebelum bel masuk berbunyi, guru memakai baju yang rapi, guru mengikuti kegiatan yang dilakukan oleh sekolah.

Keteladanan ini tercermin dari contoh dari guru di setiap aktifitas. Hal ini dijelaskan oleh guru kelas IX SD N Mojorejo 2, Sukoharjo yang menyatakan bahwa:

"Keteladanan dengan memberikan contoh perilaku yang baik karena siswa pasti akan meniru apa yang kita lakukan dibandingkan melakukan apa yang kita perintahkan. Maka saya harus memberi contoh yang baik dengan datang kesekolah lebih awal, bersikap baik dan sopan, ikut serta 
dalam melakukan kegiatan yang diselenggarakan sekolah sehingga mereka juga akan meniru."

Hal ini senada dengan pendapat Nurchaili (2010: 233) bahwa guru harus benar-benar menjadi teladan bukan hanya sebatas penyampai informasi ilmu pengetahuan, melainkan meliputi kegiatan mentransfer kepribadian yang berbudi pekerti luhur guna membentuk karakter peserta didik sebagai aset bangsa yang akan menjadi penentu eksistensi bangsa ini. Karakter merupakan perilaku (behaviour), bukan pengetahuan sehingga untuk dapat diinternalisasi oleh peserta didik, maka harus diteladankan bukan hanya diajarkan. Pelaksanaan pendidikan karakter di sekolah lebih tepat melalui pendekatan modeling, keteladanan (uswah) yang dilakukan oleh guru. Keteladanan guru perlu diciptakan karena gurulah sebagai tokoh sentral yang setiap saat menjadi perhatian peserta didik disekolah.

\section{SIMPULAN DAN SARAN}

Peran guru tidak lantas membicarakan fungsi sebagai pengajar yang hanya mentransfer ilmu dan pengetahuan. Akan tetapi guru memiliki peran dalam mendidik karakter sebagai 4 aspek, antara lain peran sebagai fasilitator, peran sebagai motivator, peran sebagai desain program, dan peran sebagai pemberi keteladanan. Hal ini yang menjadi tugas dan peran guru dalam menanamkan dan membiasakan karakter pada siswa dalam setiap kesempatan dan setiap pembelajaran. Karakter tidak lepas dari peran semua pihak, oleh sebab itu keempat aspek peran guru ketika penanaman karakter adalah dengan didukung oleh siswa itu sendiri. Karena karakter tidak bisa diukur seketika dan pada saat itu juga. Namun karakter akan menjadi roh diri siswa jika siswa benar-benar mengamalkan apa yang telah dididik oleh guru dengan sikap, perilaku dan perbuatan yang mencerminkan perilaku yang baik dan sesuai dengan aturan yang berlaku di lingkungan sekitar siswa.

\section{DAFTAR PUSTAKA}


Aqib, Z. 2012. Pendidikan Karakter Di Sekolah Membangun Karakter dan Kepribadian Anak. Bandung: Yrama Widya.

Lickona, T. 1991. Educating for Character: How Our School Can Teach. Respect and Responsibility. New York, Toronto.

Manizar, E. 2015. Peran Guru Sebagai Motivator Belajar. Tadrib, Vol.1 (2), 176188.

Milles, M.B, Huberman, A.M, \& Saldana, J. 2014. Qualitative Data Analysis, A. Methods Sourcebook, Edition 3. USA: Sage Publications

Mulyasa. 2013. Uji Kompetensi Dan Penilaian Kinerja Guru. Bandung : PT. Remaja Rosdakarya.

Nurchaili. 2010. Membentuk Karakter Siswa Melalui Keteladanan Guru. Jurnal Pendidikan dan Kebudayaan. Vol.16 (3), 230-244.

Zein, M. 2016. Peran Guru Dalam Pengembangan Pembelajaran. Jurnal Guru, Vol.5 (2), 274-285. 